\title{
A co-construção da imagem de Michel Butor: argumentação em entrevistas literárias
}

\section{The co-construction of the image of Michel Butor: argumentation in literary interviews}

\author{
Amayi Luiza Soares Koyano* \\ Universidade de São Paulo, São Paulo, SP, Brasil
}

\begin{abstract}
Resumo: $\mathrm{O}$ ethos e a argumentação são de grande contribuição para o estudo das entrevistas literárias (Yanoshevsky, 2014, 2011). Propõe-se neste artigo analisar duas entrevistas do escritor francês Michel Butor (1926-2016), tendo sido a primeira realizada no momento de comemoração dos cinquenta anos da obra de Proust, em dezembro de 1963, e a segunda, cinquenta anos depois, em celebração ao recebimento do Grande Prêmio da Académie Française pelo conjunto da obra de Butor (agosto de 2013). Com o objetivo de melhor compreender a co-construção da imagem do escritor nessas entrevistas literárias, ocorridas em dois momentos distintos de sua carreira, o artigo evidenciará, ao longo da análise, as contribuições dos entrevistadores, em especial durante a segunda entrevista, na co-construção das imagens do escritor, bem como a forma como a obra de Proust adquire, na narrativa de vida de Butor, um sentido mais amplo e, portanto, mais poético.
\end{abstract}

Palavras-Chave: Ethos. Argumentação. Michel Butor. Entrevistas literárias.

\begin{abstract}
Ethos and argumentation are of great contribution to the study of literary interviews (Yanoshevsky, 2014, 2011). In this article we propose to analyze two interviews of French writer Michel Butor (1926-2016), the first one held at the time of Proust's fiftieth birthday in December 1963, and the second fifty years later in celebration of the Académie Française Grand Prix for the whole of Butor's work (August 2013). In order to better understand the co-construction of the writer's image in these literary interviews, which occurred in two different moments of his career, we will show throughout the analysis the interviewers' contributions, especially during the second interview, in the co-construction of images of the writer, as well as the way Proust's work acquires, in Butor's narrative of life, a broader and therefore more poetic sense.
\end{abstract}

Keywords: Ethos. Argumentation. Michel Butor. Literary interviews.

\section{INTRODUÇÃO}

O ethos e a argumentação são de grande importância para os Estudos Literários e representam um avanço considerável tanto para a análise de obras literárias quanto para o estudo sobre a vida dos escritores. O estudo das imagens de si em obras literárias, no Brasil, vem sendo amplamente trabalhado por Ida Lúcia

* Mestranda em Estudos Linguísticos, Literários e Tradutológicos em Francês, Departamento de Letras Modernas, Universidade de São Paulo, São Paulo, SP, Brasil; amayi@usp.br O presente trabalho foi realizado com apoio da Coordenação de Aperfeiçoamento de Pessoal de Nível Superior - Brasil (CAPES) - Código de Financiamento 001. 
Machado (2016, 2015, 2014, 2013, 2012) e por Renata Aiala de Mello (2016, 2012), sendo também objetos de pesquisa as entrevistas de escritores brasileiros a partir do ethos e da argumentação (Oliveira, 2016), o que viabiliza a investigação da co-construção da imagem do escritor francês Michel Butor em duas entrevistas literárias (1963 e 2013), tendo por respaldo os trabalhos de Galia Yanoshevsky (2014, 2011) sobre $A$ co-construção da imagem do autor: o caso da entrevista literária e sobre L'entretien littéraire - un objet privilégié pour l'analyse du discours.

Neste artigo, tem-se por objetivo melhor compreender a co-construção da imagem de Michel Butor em duas entrevistas literárias concedidas pelo escritor em dois momentos distintos de sua carreira, sendo a primeira realizada aos 37 anos de idade do escritor (dezembro de 1963), quando ele ainda era romancista, e a segunda, aos 86 anos (agosto de 2013), após ter rompido havia quase meio século com o romance e dedicado sua escrita, sobretudo, à poesia, aos livros de artista e às parcerias com pintores e músicos. Por se tratar de entrevistas com um intervalo aproximado de 50 anos entre uma e outra, levanta-se o seguinte problema de pesquisa: houve a manutenção ou a mudança do ethos por parte do escritor ao longo desse meio século?

A compreensão da imagem co-construída que o escritor procurou transmitir por meio de entrevistas literárias faz-se necessária por ter havido, quando ainda era romancista, uma grande identificação de suas obras com a estética do novo romance francês, que encontrou na crítica literária de meados do século XX grande resistência e incompreensão (Prado, 2006) por não identificarem nessas obras neorromanescas uma herança do romance tradicional francês e por haver uma certa dificuldade e resistência dos críticos em melhor compreender a estética em questão e em estabelecer novos parâmetros de análise literária (Perugini, 2015).

Michel Butor, nascido em 1926, no norte da França, foi romancista, poeta, ensaísta literário, crítico de arte e professor universitário de Literatura Francesa na França, nos Estados Unidos, na Suíça, no Egito e na Inglaterra. Literato muito ativo, trabalhou até o fim de sua vida (2016) na escritura de poemas para amigos e em parcerias com artistas plásticos e músicos. O escritor ainda fez parte de vários livros de entrevistas, fora as concedidas ao longo de sua carreira, sendo também de sua autoria mais de dois mil livros de artistas, esculturas, desenhos e pinturas (Yanoshevsky, 2014).

Para a análise das imagens co-construídas do escritor nas duas entrevistas literárias selecionadas, a fundamentação teórica ficará a cargo dos trabalhos de Breton e Gauthier (2001), Perelman e Olbrechts-Tyteca (2005), Amossy (2011) e Oliveira (2016) na formação do panorama atual da argumentação, incluindo em seu campo de atuação as especificidades das entrevistas literárias (Yanoshevsky, 2014, 2011). Em relação ao ethos, servirão de base os trabalhos de Maingueneau (2001), Amossy (2005) e Machado (2015, 2014), também estabelecendo relação entre essas pesquisas e as entrevistas literárias (Yanoshevsky, 2014, 2011). Para a discussão dos dados levantados na análise do corpus, serão retomados os trabalhos de Maingueneau (2001), de Yanoshevsky (2014, 2011), de Machado (2015, 2014) e de Amossy (2011) devido à pertinência e à atualidade em tratar das imagens do escritor, de modo geral, e da co-construção de imagem autoral no momento específico da entrevista literária. 
Para a metodologia de análise do corpus selecionado, o presente trabalho terá como referência a pesquisa de Miranda (2011) para análise qualitativa e interpretativa por meio da seleção de lexias e locuções lexicais, constituídas de sintagmas nominais e verbais que possam fornecer características da imagem do escritor. Serão também observados os recursos argumentativos-retóricos, com foco na analogia (Miranda, 2011) e nas técnicas de dissociação argumentativa. Para tanto, foram selecionados nas entrevistas os momentos em que o escritor fala de si mesmo, de seu trabalho, da influência de outros escritores e da relação de sua obra com outras artes.

Por se tratar de entrevistas orais, faz-se necessário a adoção das normas propostas pelo Projeto da Norma Urbana Culta (Núcleo São Paulo), conforme Miranda (2011). Apesar de se tratar de entrevistas em língua francesa, as normas propostas no NURC/SP possibilitam uma transcrição fiel dos áudios, bem como sua tradução para o português, que constará na análise deste artigo. Espera-se, ao fim deste artigo, melhor traçar tanto as relações entre Michel Butor e os escritores por ele admirados quanto as do próprio escritor com as outras artes.

\section{A ARGUMENTAÇÃO EM ENTREVISTAS LITERÁRIAS}

A argumentação, de acordo com Amossy, é "entendida como a tentativa de modificar, de reorientar, ou mais simplesmente, de reforçar, pelos recursos da linguagem, a visão das coisas da parte do alocutário", sendo possível "aderir não somente a uma tese, mas também a modos de pensar, de ver, de sentir" (Amossy, 2011, p. 130) tornando basilares a interação, o contexto, as relações de poder (sociais e hierárquicas) e as questões cognitivas na composição da dinâmica argumentativa.

Oliveira afirma que "a retórica, desde a antiguidade, está unida ao estudo da argumentação" e que corresponde ao "uso de habilidades verbais na construção de uma trama que alcança o outro com eloquência e eficácia" dando origem a "uma rede", de modo que se pode considerar que "a argumentação utiliza-se de uma trama para levar o auditório à conclusão" de algo (Oliveira, 2016, p. 106-107, grifos da autora), sendo o ethos o fiador dessa trama e seu produto, a rede, a representação de mundo do enunciador (Maingueneau, 2001). A retórica, portanto, representa a base para a elaboração dessa trama argumentativa e para o exercício de fiá-la do ethos.

O papel desempenhado pela argumentação, elemento inerente à composição de um gênero discursivo, é de grande interesse da Análise do Discurso, que possibilita um trabalho profícuo na exploração do funcionamento de vários discursos muito específicos e diferentes entre si, como é o caso da entrevista com o escritor. A argumentação na entrevista literária, para Yanoshevsky (2014), age como uma maneira de tornar visível uma parcela da literatura e uma visão de mundo, sendo resultado da interação e do surgimento de um quadro que permite ao escritor produzir e inovar graças à presença e ao questionamento do entrevistador.

Para compreender melhor a argumentação, é necessário retomá-la em sua origem. Em História das Teorias da Argumentação, Breton e Gauthier (2001) traçam um panorama histórico das teorias argumentativas, destacando o fato de que os argumentos se desenvolvem em uma situação de inter-relação, possuindo uma finalidade persuasiva na busca pela adesão do interlocutor/auditório a uma crença ou a uma prática específicas. A argumentação retórica, renovada no século XX, 
estabelece o quadro ideal das teorias da argumentação. A retórica antiga constitui uma reflexão global desde a invenção de um argumento até sua aceitação ou rejeição por um auditório, tendo por interesses as situações de comunicação da vida social, religiosa e política, tanto no âmbito público quanto no privado, sendo seu estatuto epistemológico o do verossímil e não o da verdade em si.

Em sua primeira fase, argumentação e retórica são sinônimos. A retórica, em seu período fundador (meados do séc. V a.C. a meados do séc. IV a.C.), baseia-se na arte de convencer e de persuadir determinado auditório, sendo indissociável da invenção da democracia e de suas instituições. O período de maturidade da retórica, entre os anos 329 a.C. e 323 a.C., deve-se à elaboração da obra homônima de Aristóteles, que marcou, no plano teórico, o desenvolvimento desse domínio até nossos dias, de modo a inspirar a cultura da argumentação desenvolvida durante a República e que perdurou até o início do Império Romano, tendo seu período de declínio iniciado ao final deste mesmo império e se estendido até meados do séc. XX (Breton; Gauthier, 2001).

O surgimento na França da obra Tratado da argumentação - a Nova Retórica, em 1958, de Perelman e Olbrechts-Tyteca, estabelece que o argumento depende de uma racionalidade distinta da demonstração matemática e do racionalismo cartesiano, revelando-se como um esforço pela valorização da verossimilhança ao destacar a importância das opiniões em comparação aos fatos, agindo ainda como um contraponto ao êxito da demonstração proveniente das ciências exatas e experimentais e da filosofia da evidência. Ainda de acordo com Breton e Gauthier (2001), o tratado de Perelman e Olbrechts-Tyteca está inscrito na teoria aristotélica e destina-se a qualquer espécie de auditório, incluindo as deliberações de um indivíduo consigo mesmo. As entrevistas literárias, portanto, fazem parte do escopo proposto no tratado, tendo em vista seu direcionamento para uma ou mais audiências - a de leitores em geral e a de interessados especificamente em literatura francesa, por exemplo.

A teoria dos argumentos de Perelman e Olbrechts-Tyteca (2005) distingue 'argumentação', 'argumento' e 'argumentar'. Para os autores, a 'argumentação' é entendida como técnica discursiva que possibilita a evocação ou o reforço à adesão dos sujeitos às teses que lhes são apresentadas. Já o 'argumento' é a figura do discurso que apresenta forma discernível por meio de uma estrutura particular. Para eles, uma figura se torna argumentativa quando seu uso, ao desencadear uma mudança de perspectiva, apresenta-se como condizente em relação à nova situação sugerida por essa mesma figura. Por fim, 'argumentar', segundo os teóricos, é preparar e apresentar uma tese ou uma opinião a partir de uma determinada forma.

A recepção de um argumento é feita em duas fases (Breton; Gauthier, 2001). A primeira corresponde à percepção clara da recepção do enunciado como sendo este um argumento, configurando-o como parte de um desvio próprio da língua. A segunda fase, por sua vez, refere-se ao desaparecimento da percepção inicial que distingue forma e fundo. No que diz respeito à análise das técnicas argumentativas, também em dois eixos principais, estuda-se primeiro os argumentos e a sua tipologia, dentro do próprio discurso e, em seguida, a situação de comunicação constituída pelo próprio ato de argumentar, tendo em vista o efeito do discurso no auditório a partir da relação de intenção do autor desse discurso. 
Perelman e Olbrechts-Tyteca (2005) destacam ainda as quatro grandes técnicas argumentativas, que servirão de base para o estudo aqui proposto: os argumentos quase-lógicos (o entimema em Aristóteles), construídos com base no modelo lógico ou matemático (se $A$ acarreta $B$, e se $B$ pressupõe $C$, então $A$ pressupõe C); as técnicas de ligação (duas), que aproximam elementos distintos tanto pela ligação real existente entre eles quanto pela relação criada para a ocasião discursiva, em uma espécie de analogia; e as técnicas de dissociação, que separam e dissociam elementos inicialmente considerados como sendo partes de um todo.

Amossy ressalta que a análise argumentativa "leva em conta a maneira como o logos, ou o emprego de argumentos em língua natural, alia-se, concretamente, ao ethos, a imagem de si que o orador projeta em seu discurso, e ao pathos, a emoção que ele quer suscitar no outro e que também deve ser construída discursivamente" (2011, p. 134). Para o presente artigo, optou-se pela análise argumentativa do ethos, tendo em vista a particularidade da entrevista literária e o modo como esta possibilita a co-construção das imagens do autor.

As entrevistas, de modo geral, representam uma fonte importante de análise argumentativa por caracterizarem-se como canais abertos ao emprego das técnicas argumentativas descritas por Perelman e Olbrechts-Tyteca (2005) e por possibilitarem à audiência a adesão ou a refutação dos argumentos ali inseridos. $\mathrm{Na}$ análise do corpus selecionado, será possível constatar a presença dessas técnicas argumentativas e o modo como elas interagem entre si dentro do discurso para constituírem o ethos, ou os ethé múltiplos por meio da co-construção da imagem do escritor francês Michel Butor. Percebe-se, a partir da discussão acerca da argumentação e da introdução das especificidades da entrevista literária, a necessidade de se apresentar um breve estudo do ethos antes da análise do corpus.

\section{O ETHOS EM ENTREVISTAS LITERÁRIAS}

A relação estabelecida na vida do ser humano, independente das variáveis às quais está sujeita (financeiras, intelectuais, habitacionais, familiares, dentre outras) é descrita por Bakhtin (2008) como o ciclo de vida-crescimento-morte-renascimento. O constituinte crescimento desse ciclo bakhtiniano pode ser entendido, nos discursos, como a junção dos fatores trabalho, ensinamentos e relações interpessoais, sendo esses três admitidos em suas mais variadas formas. As ligações que esses três fatores estabelecem com a produção linguageira estão, em graus variados, presentes nos discursos, o que possibilita a análise das imagens de si (o ethos ou os ethê) nas obras e nas entrevistas literárias.

Em $O$ contexto da obra literária, Maingueneau pontua que a "retórica antiga compreendia por ethé as propriedades que os oradores se conferem implicitamente através de sua maneira de dizer: não o que dizem explicitamente sobre si próprios, mas a personalidade que mostram através de sua maneira de se exprimir" (2001, p. 137, grifos do autor). Amossy completa essa afirmação ao constatar que "os antigos designavam pelo termo ethos a construção de uma imagem de si destinada a garantir o sucesso do empreendimento oratório", sem se importarem com o grau de sinceridade que conferiam ao discurso proferido, tendo como objetivo apenas causar boa impressão por meio de "seu jeito" (2005, p. 10, grifo da autora). Desse modo, a eficácia do ethos 
se relaciona ao modo como este envolve a enunciação, sendo, sobretudo, um mostrar-se através de sua maneira de se expressar.

As várias correntes da Análise do Discurso e da Pragmática, hoje, ao privilegiarem "o emprego do enunciado em situação e a força da palavra [...] reencontram a Retórica definida como a arte de persuadir. À maneira de Aristóteles, procuram compreender e explicar como o discurso se torna eficaz" (Amossy, 2005, p. 10). Portanto, é pertinente a ampliação da percepção de ethos, visto que, na retórica antiga, foi "conceitualizado para analisar os discursos dos oradores" (Maingueneau, 2001, p. 138). Para Maingueneau, é preciso

\begin{abstract}
admitir que qualquer gênero de discurso escrito deve gerir sua relação com uma vocalidade fundamental. $\mathrm{O}$ texto está sempre relacionado a alguém, uma origem enunciativa, uma voz que atesta o seu dito. Levar em conta o etos de uma obra não implica que se volte aos pressupostos da retórica antiga, que se considere o escrito como o vestígio, o pálido reflexo de uma oralidade primeira. Trata-se antes de levar em consideração a maneira como a cenografia gere sua vocalidade, sua relação com a voz. (Maingueneau, 2001, p. 139, grifo do autor).
\end{abstract}

Ethos, portanto, implica "um policiamento tácito do corpo, uma maneira de habitar o espaço social" e, em relação aos escritores e artistas de modo geral, "constitui-se através de um conjunto de representações sociais do corpo ativo em múltiplos domínios" (Maingueneau, 2001, p. 139). Através da música, do cinema, da fotografia, da literatura, entre outros, circulam formas de se esquematizar o corpo, sejam elas valorizadoras ou desvalorizadoras, demonstrando a variedade de modos de presença no mundo. O ethos permite que a obra se corporifique para $o$ co-enunciador, ou seja, ele molda a obra, dando a ela uma forma possível de habitar no mundo. O ethos, desse modo, "parece indissociável de uma 'arte de viver', de uma 'maneira global de agir"' (Maingueneau, 2001, p. 147).

A construção de uma imagem de si é a peça de maior importância na retórica e possui forte vínculo com a enunciação, sendo as reformulações e os debates em torno da noção de ethos fruto dos resgates e dos abandonos que as ciências da linguagem estabelecem com Aristóteles (Amossy, 2005). A noção de ethos é entendida, ainda, como um articulador que recusa qualquer ruptura entre o texto e o corpo do enunciador, como também entre o mundo representado e a própria enunciação que o carrega, sendo sua qualidade remetida a de "um fiador, que através desse etos se proporciona uma identidade à medida do mundo que supostamente deve fazer surgir" (Maingueneau, 2001, p. 142).

Para Machado, "ao tomar a palavra para falar de si, o indivíduo se autoconstrói", de modo que "a narrativa de vida ajuda aquele-que-se-narra a melhor se definir face ao outro pelo trabalho que empreende ao elaborar uma imagem de si que opere uma reunião de suas experiências passadas com seu percurso atual" (2014, p. 1130-1131, grifos da autora). Ou seja, a imagem de si do enunciador é constituída de experiências passadas (essencialmente memórias) unidas ao percurso atual de vida desse sujeito no momento da enunciação e em partilha com um outro enunciador. $\mathrm{O}$ enunciado ganha forma corpórea graças ao ethos e em função de seu co-enunciador, sendo que este, no caso da entrevista literária, é também co-criador desse ethos do escritor no momento da fala. 
Vida e obra, apresentados por Bakhtin (2008) no início dessa discussão, ilustram claramente a percepção de Machado $(2015,2014)$ sobre as imagens de si, sendo para ela definidas como "narrativas de certos homens e mulheres com o fim de mostrar como essas vidas se mostram imbricadas na profissão, no trabalho e como um não prescinde do outro" (Machado, 2015, p. 85). Para a pesquisadora, a narrativa de vida é uma prática discursiva ampla e que surge de diversas formas, sem aviso prévio. Percebe-se, com isso, um certo estreitamento das imagens de si de grande importância para o presente estudo, pois há como foco central a busca pela narrativa de vida vinculada à profissão, transformando vida e obra numa só via, como exemplificadas pelo escritor Michel Butor em suas entrevistas literárias.

A narrativa de si, que é a própria imagem de si, o ethos, pode se apresentar de forma sutil e aparecer em um discurso por intermédio de uma palavra ou de um tom, de um modo de narrar, que age como um canal de acesso à memória ou ao passado do sujeito que se narra. Essa narrativa pode surgir tanto em entrevistas com objetivos específicos quanto em poemas, letras de música ou romances que se constroem ao estilo da autoficção (Machado, 2014). No caso da entrevista com objetivos específicos, "o estudo da entrevista [literária] mostra a co-construção da imagem de autor na dinâmica do diálogo" (Amossy, 2011, p. 139). Yanoshevsky ressalta que "não é simplesmente uma só imagem que é colocada em jogo na entrevista, mas uma pluralidade de imagens, visto que o entrevistado possui várias delas em função de seu caráter e de seu papel institucional" (2011, não paginado, grifos da autora). A entrevista literária é, portanto, dialógica, e

[...] nasce de uma negociação entre o entrevistador e o entrevistado, cada um levando a entrevista para o seu lado - o primeiro para representar o entrevistado e satisfazer a demanda dos leitores, o segundo com o objetivo de construir um éthos que lhe convém por motivos que vão da promoção da sua obra à correção da sua imagem preestabelecida. A entrevista constitui, desse modo, o resultado da confrontação da imagem discursiva com a imagem prévia do entrevistado, que é frequentemente esquemática e simplista, enquanto que a entrevista exibe para o público as múltiplas e diversificadas facetas do autor. Além disso, a presença de outra consciência além da do escritor e sua contribuição é de uma importância inestimável. É graças à participação do entrevistador, graças ao diálogo que se estabelece entre ele e o escritor, que a entrevista é um lugar produtor de sentidos que oferece uma riqueza e uma complexidade - em particular em relação à imagem de si — que não se encontra em nenhum outro lugar. (Yanoshevsky, 2011, não paginado, grifo da autora).

É por meio da entrevista literária, de natureza dialógica, que o escritor co-constrói com o entrevistador imagens de si, de modo que estas podem ou não conter elementos de sua vida privada. No caso de Michel Butor, como será evidenciado a seguir, ao co-construir sua imagem com a entrevistadora, na segunda entrevista (2013), ele mescla sua própria narrativa de vida à imagem de si que ele constrói, ao incluir elementos bio-gráficos de seu fazer literário em seu enunciado (Maingueneau, 2001). 


\section{A CO-CONSTRUÇÃo DA IMAGEM DE MICHEL BUTOR: ENTRE O ESCRITOR E O FAZER LITERÁRIO}

\subsection{Michel Butor, o herdeiro de Proust}

Em celebração ao cinquentenário da publicação do primeiro volume de Em busca do tempo perdido, de Marcel Proust, a RTF organizou o especial Proust aujourd'hui, produzido por Robert Valette e Georges Gravier, com a participação de grandes nomes da literatura e da crítica literária da época. Na segunda emissão do especial, $L a$ leçon de Marcel Proust selon Michel Butor, de 10 de dezembro de 1963, o escritor fala sobre a influência que a leitura contínua da obra de Proust exerce em seu trabalho e em sua prática de leitura. Após uma curta apresentação do programa, o entrevistador, Robert Valette (identificado como E1 nas transcrições), expõe uma breve reflexão sobre o leitor de Proust e os efeitos de leitura de sua obra. Toda a entrevista terá como ponto de partida esta única pergunta do entrevistador, sendo o restante do tempo dedicado à resposta de Butor (identificado como MB1 nesta transcrição), sem interferências do entrevistador:

E1: o leitor de Proust:: tem o sentimento de entrar de cabeça no reino do espírito... desde as primeiras páginas do Tempo perdido:: um tipo de êxtase::... uma agonia extasiada o domi::na... é com confiança que ele se deixa conduzir::... a essa longa busca na qual se desenvolve continuamente::... a ampla doçura da paciência e da atenção... a obra de Proust::... a realização de seu ato de escritor:: deram origem a um ato talvez perfei::to... por seu próprio:: ato por sua necessidade de agir:.... à sua própria maneira:: que lição o escritor extrai? para o próprio escritor... qual é a lição de Proust::? Michel Butor::...

É interessante observar as lexias por ele escolhidas como importantes. A maioria dentre elas relacionam-se diretamente a Proust e à sua obra: Proust::, Tempo perdido::, tipo de êxtase::...., domi::na:..., a realização de seu ato de escritor:: deram origem a um ato talvezperfei::to... . Os argumentos empregados conferem a Proust e à sua obra imagens bastante positivas e que representam um ideal que todo escritor busca atingir. As demais lexias representam um tipo de dependência entre os outros escritores e os feitos de Proust, por meio do uso de argumentos quase-lógicos: por sen próprio:: ato por sua necessidade de agir::... à sua própria maneira::... . Para que o escritor (A) consiga, ao seu modo, criar uma obra da mesma importância que Em busca do tempo perdido (C), ele precisa seguir os passos de Proust (B); não há atalhos na busca pela perfeição.

No que diz respeito ao entrevistado, não há qualquer apresentação sobre seus feitos literários; é apenas enunciado o seu nome, Michel Butor:: O ethos do escritor, criado pelo entrevistador, está diretamente vinculado ao ethos de leitor e ao do próprio Proust, por meio da técnica de ligação - aproximar elementos considerados diferentes através de uma relação criada durante o próprio ato argumentativo. A única regra da entrevista, implícita, portanto, é a de discorrer sobre a relação de leitura com a obra proustiana, ressaltando as lições aprendidas e apreendidas. $\mathrm{Na}$ época dessa entrevista, Butor já havia recebido os prêmios Fénéon e Renaudot, em 1957, e o Prix de la Critique Littéraire, em 1960, tendo sido muito aclamado pelo seu terceiro romance, La Modification (1957), o que parecem justificar a sua participação nesse especial, mas que não foram ditos pelo entrevistado. 
A imagem que Butor cria de si mesmo é divergente da que o entrevistador projeta em sua pergunta, criando uma ruptura e uma tensão entre ambos os ethé presentes na entrevista por meio da técnica de dissociação entre seus argumentos e os do entrevistador.

MB1: para MIM a obra de Proust NÃO:: me dá... não me deu ao menos quando eu li esse contentamento extasia::do... eu me lembro muito bem que quando eu li pela primeira vez... Proust:... já faz alguns ANOS... eu tive certa dificuldade de entrar no interior desse mundo... porque:: há muitas coisas que são estranhas à minha experiência ( ) TODA a parte do faubourg Saint-Germain... mundano... belle époque:: se preferir... da obra de Proust::... foram para mim obstáculos consideráveis... é:: SOMENTE... ao final de mil pá::ginas mais ou me::nos que eu comecei a achar ISSO interessan::te... e ao final de duas mil pá::ginas eu achei isso apaixonante... eu achei isso tão apaixonante que:: eu me DISPUS:: a estudá::-la e... depois eu:: recomecei esse estudo algumas ve::zes então esses estudos me levaram a escrever um certo número de textos SOBRE a obra de Proust::... é certo que a partir do momento em que me dispus:: a REALMENTE:: achar que isso valia a pena de ser estuda::do... e BEM a obra de Proust teve para mim um ensinamento considerável... há uma QUANTIDADE de coisas que nunca teria FEITO... se Proust não tivesse existi::do... se eu não tivesse lido Proust... Proust foi certamente para mim um APOIO considerá::vel

Percebe-se, acima, uma espécie de chamado encontrado pelo escritor na obra de Proust, uma vocação enunciativa (Maingueneau, 2001). Ao partir do interesse pela obra por meio da leitura, o escritor se sente impelido a estudá-la mais sistematicamente. Por intermédio desses estudos, Butor torna-se aluno de Proust, sendo possível realizar feitos na literatura que, segundo ele, não seria possível sem a compreensão do modus operandi proustiano, que ele considera como ensinamentos adquiridos do escritor. Ele se sentiu "chamado a produzir literatura" (Maingueneau, 2001, p. 78) a partir da obra proustiana, na época desta entrevista. Ele vincula, portanto, seu fazer literário ao de Proust, tornando-se seu herdeiro dentro do novo romance francês. A ênfase dada às lexias QUANTIDADE de coisas e APOIO reforçam ainda mais os argumentos de Butor, de que ele foi ajudado diretamente por Proust e que sua produção literária está, portanto, relacionada a Em busca do tempo perdido, sendo possível partir desses argumentos para propor análises entre seus romances e o de Proust. Ele continua:

MB1: então para tentar evidenciar... as linhas principais desse ensinamento ISSO é algo de muito difícil::... há um primeiro ensinamento:: que É um ensinamento... eu diria::... um ensinamento técnico:: sobre o modo de fazer um li::vro... é que me levou a me interessar realmente na obra de Proust É:: seu caráter arquitetural... e esse caráter arquitetural ele só se evidencia MUITO LENTAMENTE::...

Novamente, vê-se a ênfase dada por Butor em algumas lexias muito significativas. No primeiro caso, a ênfase em ISSO retoma todos os argumentos ditos anteriormente - então para tentar evidenciar... as linhas principais desse ensinamento -, culminando no prolongamento de difícil:: , o que ressalta a complexidade sentida por Butor em descrever a importância de Proust em sua vida por meio dos ensinamentos por ele aprendidos. Essa dificuldade de aproximação da obra proustiana inicialmente

${ }^{1}$ Do original em francês: $C A$ c'est quelque chose de très difficile::... . 
por meio da leitura, apresentada no início da entrevista, persiste. Não é só a leitura da obra de Proust que apresenta obstáculos; pensar e dizer de sua importância enquanto escritor é também um desafio considerável, o que evidencia em Butor um ethos não só de aluno, mas de bom aluno, dedicado, compromissado com o próprio aprendizado e que respeita seu mestre, estando também apto a superar as próprias limitações diante de uma criação maior, como é o caso da obra de Proust para ele.

A técnica de prolongamento lexical como forma de dar visibilidade às lexias mais importantes substitui à de ênfase: há um primeiro ensinamento:: que é um ensinamento... eu diria:: um ensinamento técnico:: sobre o modo de fazer um li::vro ${ }^{2}$, indicando um cuidado na escolha das lexias, tomando para si (eu diria::) os argumentos apresentados. O que se pode inferir do modo de apresentação desses argumentos é que li:vvro apresenta para Butor o ponto central desse primeiro ensinamento. $\mathrm{O}$ domínio das técnicas de se fazer um livro, no caso um romance, não pode vir senão como ensinamento de Proust. De todas as lexias destacadas por Butor, li::vro é, portanto, a mais importante dentre elas por representar o objetivo primeiro e final de um escritor: a criação literária gera textos que se tornam livros.

Referindo-se diretamente à obra de Proust, Butor prossegue sua argumentação ao apresentar a arquitetura de Em busca do tempo perdido como um dos seus principais interesses no fazer literário proustiano: o caráter arquitetural da obra evidencia-se MUITO LENTAMENTE:: não sendo, portanto, possível uma compreensão e um maravilhamento imediatos da obra de Proust, como apresentados pelo entrevistador. Novamente, Butor transparece o conflito entre a imagem criada por ele e a apresentada pelo entrevistador por meio da técnica de dissociação.

MB1: Proust:: admirava muito Monet e há uma série de telas de Monet que particularmente o inspiraram:: É a série de telas sobre a catedral de Rouen:: ESSA IMAGEM da catedral ou do edifício que aparece pouco a pouco através de um nevoeiro:: essa imagem a gente a reencontra muito na Busca do tempo perdido:: e ao final naturalmente Proust comparará sua própria obra... a uma catedral em parte:: e também:: como vocês sabem:: a um vestido:: e bem evidentemente essa catedral que é a obra de Proust é uma catedral que aparece pouco a pouco na névoa:: é uma o::bra por consequência que exi::ge da parte do seu leitor um certo TEMPO... ela é lon::ga ela é fundamentalmente lon::ga porque:: é PRECISO absolutamente que o leitor se aproxime pouco a pouco diante desse edifício... é preciso por consequência que esse edifício seja escondido por alguma coisa:: escondido por uma névoa ( ) dos primeiros momentos da leitura de Proust:: é pouco a pouco somente que a gente vê as LINHAS as MASSAS se ordenarem:: é a partir desse momento que:: realmente para mim houve um ensinamento considerável... um ensinamento em parte na arquitetu::ra nessa arquitetura IMEN::SA de uma complexidade maravilho::sa com todo tipo de esconderijo e de nicho:: todo tipo de detalhes que aparecem:: MAS uma lição também naturalmente no que eu posso chamar:: o efeito de névoa:: o FAto que a obra se descobre lentamente:: a obra de Proust:: é para ele mesmo um monumento que se descortina da névoa:: é pouco a POUCO que ele se dispõe a compreender ele mesmo:: um pouco... o que ele fazia e o que ele sentiu:: as dimensões e a importância do edifício que ele estava construindo::...

\footnotetext{
${ }^{2}$ Do original em francês: il y a un premier enseignement:: qui EST un enseignement... je dirais:.... un enseignement technique:: sur la façon de faire un li::vre... .
} 
As ênfases corroboram para os prolongamentos ${ }^{3}$ nas demais lexias, por exemplo: o destaque em É reforça a inspiração de Proust pelo trabalho de Monet; ESSA IMAGEM retoma tanto a importância dessa inspiração quanto a presença dela na obra proustiana, bem como as LINHAS as MASSAS e IMEN::SA. Ao tratar especificamente do efeito de leitura gerado pela arquitetura da obra, Butor faz uso dos prolongamentos nas lexias que vieram da relação do romance de Proust com a série de Monet: Proust::, inspiraram::, a série de telas sobre a catedral de Rouen::, do edifício que aparece pouco a pouco através de um nevoeiro::, aparece pouco a pouco na névoa::, é uma o:: bra por consequência que exi::ge da parte de seu leitor, ela e lon::ga ela e fundamentalmente lon:::ga, esse edificio seja escondido por alguma coisa::, de uma complexidade maravilho::sa, todo tipo de esconderijo e de nicho:: todo tipo de detalhes que aparecem::; efeito de névoa::, a obra se descobre lentamente::, um monumento que se descortina da névoa:: A partir desses prolongamentos, Butor mostra a estrita relação entre a obra de Proust e a pintura impressionista de Monet.

MB1: então é certo que:: no modo de organizar um li::vro... e bem eu:: aprendi:: imensamente nos estudos de Proust:: e no modo também de fazer:: aparecer:: pouco a pouco alguma coisa:: um dos ensinamentos maiores para MIM para:: meu próprio trabalho da obra de Proust é que:: o efeito imediato de um li::vro é alguma coisa de completamente secundá::ria em relação:: ao lugar que ele vai adquirir pouco a pouco:: uma das coisas que:: Proust me ensinou:: na leitura mesmo que eu fiz:: é que:: uma obra dessa importância uma obra dessa dimensão:: a gente só apreende lentamente e:: que isso não é um acidente:: que é alguma coisa que essa LENTIDÃO essa dificuldade de aproximação dificuldade::... que pode ser delicio::sa... que essa dificuldade seria alguma coisa de absolutamente INDISPENSÁVEL se a gente quiser superar um certo nível

Para discursar sobre a influência de Proust em seu trabalho, Michel Butor destaca as lexias MIM, LENTIDÃO e INDISPENSÁVEL, empregando o prolongamento nas demais que corroboram para a compreensão de seus argumentos ${ }^{4}:$ no modo de organizar um li::vro, eu:: aprendi:: imensamente nos estudos de Proust::, e no modo também de fazer:: aparecer:: pouco a pouco alguma coisa::, para:: men próprio trabalho, é que:: o efeito imediato de um li::vro é alguma coisa [...] secundá::ria em relação:: ao lugar que ele vai adquirir pouco a pouco::, uma obra dessa dimensão::, isso não é um acidente::, essa dificuldade de aproximação dificuldade::... que pode ser delicio::sa. Compreende-se, nesses enunciados, o motivo de Butor ter incluído em sua fala anterior uma explicação mais completa da arquitetura da Recherche e de sua fonte, a série de quadros de Monet sobre a catedral de Rouen, datadas entre 1892 e 1894. Ao dar sequência e incluir o seu próprio fazer literário, ele ressalta que, por meio dos estudos que realizou sobre a obra de Proust, aprendeu a organizar e a estruturar um livro.

\footnotetext{
${ }^{3}$ Do original em francês: Proust::, inspiré::, la série de toiles sur la cathédrale de Rouen::, l'édifice qui apparaît peu à peu à travers un brouillard::, apparaît peu à peu dans la brume::; c'est une cu::vre qui exi::ge de la part de son lecteur, elle est lon::gue elle est fondamentalement lon:: gue, cet édifice soit caché par quelque chose::, d'une complexité merveilleu::se, toute sorte de recoin et de niche:: toute sorte de détail qui apparaissent::; effet de brume::: l'cuvre se découvre lentement::; un monument qui se dégage de la brume::.

${ }^{4}$ Do original em francês: dans la façon d'organiser un li::vre, j'ai:: énormément appris:: dans l'etude de Proust::, dans la façon aussi de faire:: apparaître:: peu à peu quelque chose::, pour:: mon propre travail, c'est que:: l'effet immédiat d'un li::vre est [...] secondai::re par rappor::t à la place qu'il va prendre peu à peu::, une cuvre de cette dimension::, ce n'est pas un accident::, difficulté d'approche difficulté::... qui peut être délicieu::se.
} 
Assim como Proust compara sua obra a uma catedral, Butor compara o seu trabalho ao de edificação de uma construção. Esses argumentos por analogia ligam-se diretamente aos argumentos quase-lógicos, de tal forma que, como demonstrado por meio das lexias destacadas e prolongadas, eles sozinhos já trazem toda a lógica da argumentação e resumem o ato de argumentar butoriano. O ethos apresentado por Butor é de escritor-construtor, que utiliza da percepção de Proust sobre como deve ser um romance-catedral e das referências de edificação presentes em outras artes - nas telas de Monet, por exemplo - para forjar sua própria obra. Para apresentar esse ethos de escritor-construtor, Butor retoma a ideia presente em seus argumentos anteriores, de se apresentar como aprendiz esforçado e dedicado, que consegue, através de boas referências e de muito trabalho, edificar suas obras, opondo-se, por meio da técnica de dissociação, à imagem preestabelecida pelo entrevistador no início da entrevista. Percebe-se até aqui que, apesar de o escritor responder a uma única pergunta do entrevistador, todos os argumentos dissociativos por ele empregados respondem a essa única pergunta, que tem essa imagem criada de leitor ideal proustiano ressoando ao longo de toda a entrevista, evidenciando tanto o caráter dialógico da entrevista literária (Amossy, 2011) quanto a multiplicidade de imagens geradas no decorrer dela (Yanoshevsky, 2011). É por meio do falar de si, de sua experiência de leitura e de escritura, que Michel Butor se autoconstrói (Machado, 2014), sendo essa autoconstrução no momento da entrevista literária bastante maleável e aberta à contra-argumentação e às contribuições dos entrevistadores (apesar de isso só ocorrer na segunda entrevista). Em todo caso, percebe-se que há tanto uma fluidez na construção do ethos quanto seu caráter de processo construtivo, sendo resultado de toda uma trama argumentativa (Oliveira, 2016), que não pode ser apreendida de imediato pelo espectador. É somente ao fim de todo o quadro enunciativo da entrevista literária que a audiência conseguirá ter a dimensão geral das imagens co-construídas.

Retomando essa primeira entrevista, é necessário, ainda, destacar o ensinamento proustiano dentre os de maior relevância para a compreensão da obra de Michel Butor que o acompanha em toda sua carreira, também presente na segunda entrevista:

MB1: uma das coisas que a obra de Proust mais me trouxe é o papel que ele faz desempenhar as obras de arte:: PROUST ME ENSINOU MUITO SOBRE A MÚSICA SOBRE A PINTU::RA E:: SOBRE A LIGAÇÃO ABSOLUTAMENTE ESSENCIAL que essas duas atividades do espírito têm com essa terceira que é:: a literatu::ra ${ }^{5}$

Além do aprendizado sobre como fazer um livro, Butor herdou de Proust a possibilidade de se estabelecer relações entre literatura, pintura e música. A ênfase dada em toda a locução lexical PROUST ME ENSINOU MUITO SOBRE A MÚSICA SOBRE $A$ PINTU::RA E SOBRE A LIGAÇÃO ABSOLUTAMENTE ESSENCLAL evidencia não só a importância dessa lição para a obra de Michel Butor, como também a amplitude que essa mesma ligação, por ele considerada como absolutamente essencial, guiará toda a sua trajetória enquanto escritor. Nota-se, ainda, o prolongamento dado em PINTU::RA,

\footnotetext{
${ }^{5}$ Do original em francês: une des choses qui dans l'auvre de Proust m'a le plus apporté c'est le rôle qu'il fait jouer:: aux cuvres d'art:: PROUST M'A BEAUCOUP APPRIS SUR LA MUSIQUE SUR LA PEINTU::RE ET:: SUR LA LIAISON ABSOLUMENT ESSENTIELLE que ces deux activités de l'esprit ont avec cette troisième qui est:: la littératu::re.
} 
o que parece, dentro da frase, estabelecer uma hierarquia entre esta arte e a música, estando a pintura em primeiro plano, e na conjunção $E::$ que destacará a ligação entre essas artes e a literatura. Os demais prolongamentos recaem sobre o papel que ele far. desempenhar as obras de arte:: e que é:: a literatu::ra, ambas relacionando-se diretamente à locução em que foi dada ênfase.

Apesar de a presença de Proust, ao longo da segunda entrevista, não passar de rápida citação sobre a leitura do romance proustiano - Em busca do tempo perdido tem sua BOA EXTENSÃO (Butor, 2013, não paginado) - em meio a vários outros nomes de autores que, ao longo dos anos serão também por ele estudados, é possível perceber a reverberação de vários pontos apresentados por ele nessa entrevista de 1963. O ponto central dela, principalmente se comparada à entrevista a seguir, é a constância tanto da apresentação das imagens de si do escritor quanto da manutenção de seu interesse por sempre buscar em suas obras essa ligação que ele considera absolutamente essencial entre literatura, pintura e música.

\subsection{A imagem de Michel Butor cinquenta anos depois}

Na segunda entrevista (03 de agosto de 2013), cinco décadas após a primeira, Michel Butor (identificado como MB2 nesta transcrição) é o convidado especial do programa de entrevistas literárias $\grave{A}$ double titre, apresentado pela jornalista Catherine Fruchon-Toussaint (identificada como E2). Diferentemente da primeira, o foco desta passa a ser toda a trajetória do escritor.

\footnotetext{
E2: BOM DIA MICHEL BUTOR

MB2: BOM DIA

E2: e para começar os nossos parabéns por esse GRANDE PRÊMIO DE LITERATURA que você acaba de receber da ACADÉMIE FRANÇAISE::... uma recompensa pelo conjunto de sua OBRA... e QUE OBRA... eu acredito que essa emissão À double titre não será suficiente para FALAR dela... na sua totalidade é preciso HORAS e como você nos FEZ a honra de estar aqui hoje nós vamos com você PERCORRER em sua memória:: e descobrir alguns títulos de cinema... de poesia de... música:: todas essas expressões artísticas que ALIMENTAM:: seu próprio trabalho::... trabalho:: ECLÉTICO ( ) pois este ANO você publicou três O::BRAS E um DISCO em áreas bem diferentes um LIVRO DE ARTE intitulado Une nuit sur le mont Chauve com Miquel Barcelo para quem você compôs poemas... um ensaio Conversation sur le temps com Carlo Ossola... e um livro para crianças Les trois châteaux:: um triângulo literário publicado pelas edições la Différence:: aos quais é preciso incluir um DISCO DE JAZZ::... Le long de la plage::... com o pianista Marc Copland E eu cito APENAS os últimos lançamentos porque se eu incluo que suas Euvres Complètes foram publicadas em DOZE VOLUMES:: pelas edições la Différence:: nossos ouvintes compreendem a DIMENSÃO da AMPLITUDE e da diversidade de seu trabalho de poeta... de ensaísta... de crítico... de romancista::... uma vida INTEIRAMENTE consagrada à arte e:: à escritura::... isso NÃO lhe dá vertigem... Michel Butor?
}

Para apresentar Michel Butor, E2 recorre à ênfase nas lexias que dizem respeito à produção literária do escritor: GRANDE PREAMIO DE LITERATURA que você acaba de receber da ACADÉMIE FRANCCAISE:... uma recompensa pelo conjunto de sua OBRA... e QUE OBR A...; en acredito que essa emissão À double titre não será suficiente para FALAR dela... na sua totalidade é preciso HORAs; todas essas expressões artísticas que ALIMENTAM:: seu próprio trabalbo::... trabalho:: ECLÉTICO () pois este ANO você publicou três O::BRAS E um DISCO em 
áreas bem diferente um LIVRO DE ARTE; é preciso incluir um DISCO DE JAZZ:....; E eu cito APENAS os últimos lançamentos; suas QEuvres Complètes foram publicadas em DOZE VOLUMES::; nossos owvintes compreendem a DIMENSÃO da AMPLITUDE $e$ da diversidade de seu trabalho; uma vida INTEIRAMENTE consagrada à arte e:: à escritura::... . Percebe-se que o argumento desenvolvido no início da entrevista busca nos feitos do escritor elementos para a argumentação da entrevistadora. É por meio do valor que se atribui aos atos apresentados de Butor que se incita a audiência a atribuir o mesmo valor ao próprio escritor. O recebimento do Grande Prêmio de Literatura da Académie Française, bem como toda a sua produção, podendo ainda se abranger para "tudo quanto pode ser considerado emanação da pessoa, sejam eles ações, modos de expressão, reações emotivas, cacoetes involuntários ou juízos" (Perelman; Olbrechts-Tyteca, 2005, p. 339) se integram à imagem do escritor criada pela entrevistadora e apresentada à audiência. Em outras palavras, a partir da enunciação de E2, Michel Butor torna-se sua própria obra por meio da teia argumentativa desenvolvida pela jornalista.

Entretanto, a pergunta da entrevistadora - isso NÃO lhe dá vertigem... Michel Butor? -, construída de forma bastante direcionada, parece contrariar a argumentação precedente, de associar a criação ao escritor. Ao utilizar de técnica dissociativa, entre tudo o que foi dito que o escritor criou e a suposição de que há um sentimento de síncope ao constatar sua própria criação, E2 introduz argumentos de dissociação do par aparência-realidade. Visando melhor delimitar a imagem do escritor por ela construída, ocorre a ênfase no elemento de negação $N \tilde{A O}$, que evidencia o objetivo de apresentar uma imagem do escritor que seja real e não apenas criada com base nos atos de Butor por ela apresentados. A entrevistadora não considera possível que o escritor contemple a própria obra com encantamento e maravilhamento, orientando a pergunta para uma única sensação aceitável. No entanto, ela não o desqualifica enquanto escritor capaz de uma criação grandiosa quanto a dele e nem há como objetivo o de o constranger perante a audiência; ao contrário: ela busca valorizar o seu lado de homem comum (Perelman; Olbrechts-Tyteca, 2005), que trabalha muito - uma vida INTEIRAMENTE consagrada à arte e:: à escritura:... - e que não vê a própria obra como um dom, mas como resultado de décadas de dedicação.

Para responder a essa questão, Butor concorda com a entrevistadora e apresenta, como ocorre na primeira entrevista, seu ethos de escritor humilde diante de sua própria criação:

MB2: quando eu vejo:: o número de livros que eu publiquei:: isso me dá vertigem

E2: quantos exatamente?

MB2: isso é muito difícil de dizer... percebe? porque:: tem livros normais::... os livros que são publicados pelas editoras... impressos como esses livros que você acaba de falar e TAMBÉM tem OS LIVROS DE ARTISTA:: os livros de artista que são algumas vezes impressos:: que são algumas vezes manuscritos... algumas vezes REPRODUZIDOS a gente faz todo tipo de procedimentos:: e então desses eu fiz muitos

E2: mais de mil sem dúvida

MB2: mais de DOIS MIL

E2: MAIS DE DOIS MIL

MB2: isso isso... então ((riu)) evidentemente é difícil:: de:: ADMINISTRAR tudo:: isso... de ORGANIZAR tudo isso... de achar tudo isso na minha casa... então minha casa é cheia de livros:: ela é cheia dos livros DOS OUTROS sobretudo MAS ela é cheia também dos MEUS LIVROS... então os livros dos outros eu consigo encontrar porque eles estão bem organizados... 
meus próprios livros:: eu tenho muita dificuldade de achar apesar de todo o meu esforço:: porque para os achar eu fiz um catálogo com meu computador:: então:: eu sei mais ou menos onde eu DEVO achar tal livro::

Ao falar da variedade e da quantidade de suas obras, Butor destaca as lexias por meio da ênfase e do prolongamento vocálico ${ }^{6}$ : TAMBÉM tem OS LIVROS DE ARTISTA:: os livros de artista que são algumas vezes impressos:: que são algumas vezes manuscritos... algumas vezes REPRODUZIDOS a gente faz todo tipo de procedimentos::, diferenciando essa sua criação da que ele chama de os livros que são publicados pelas editoras... impressos como esses livros que você acaba de falar. Essa diferenciação não pressupõe uma hierarquização entre suas obras, mas ilustra tratar-se do que a própria entrevistadora denomina de trabalho:: ECLÉTICO ${ }^{7}$ no início da entrevista, que não foi por ela listado entre os feitos do escritor, sendo um elemento que ele considera importante em sua criação. $\mathrm{Na}$ sequência, ocorre ainda a ênfase nas lexias que correspondem ao número de livros de artista já produzidos por ele - mais de DOIS MIL - seguidas da enunciação da jornalista, que repete o enunciado de Butor expandindo a ênfase para o advérbio de quantidade - MAIS DE DOIS MIL.

Dando continuidade à entrevista, Butor, novamente, faz uso de ênfase em lexias que são importantes para a constituição do seu ethos de escritor. No enunciado então ((riu)) evidentemente é difícil:: de:: ADMINISTRAR tudo:: isso... de ORGANIZAR tudo isso..., percebe-se que o escritor destaca os verbos de ação para tratar da ordenação dos próprios livros, sendo essa ênfase relacionada aos prolongamentos ${ }^{8}$ em difícil:: de:: e tudo:: isso... que enquadram o primeiro verbo enfatizado. $\mathrm{O}$ escritor afirma então minha casa é cheia de livros:: ela é cheia dos livros DOS OUTROS sobretudo MAS ela é cheia também dos MEUS LIVROS..., destacando as lexias DOS OUTROS, MAS e MEUS LIVROS, o que cria uma certa oposição pela ênfase na conjunção de valor adversativo posta entre as duas demais lexias enfatizadas.

Ainda sobre a produção do escritor, a entrevistadora questiona se Butor não seria imbuído de uma compulsão por escrever:

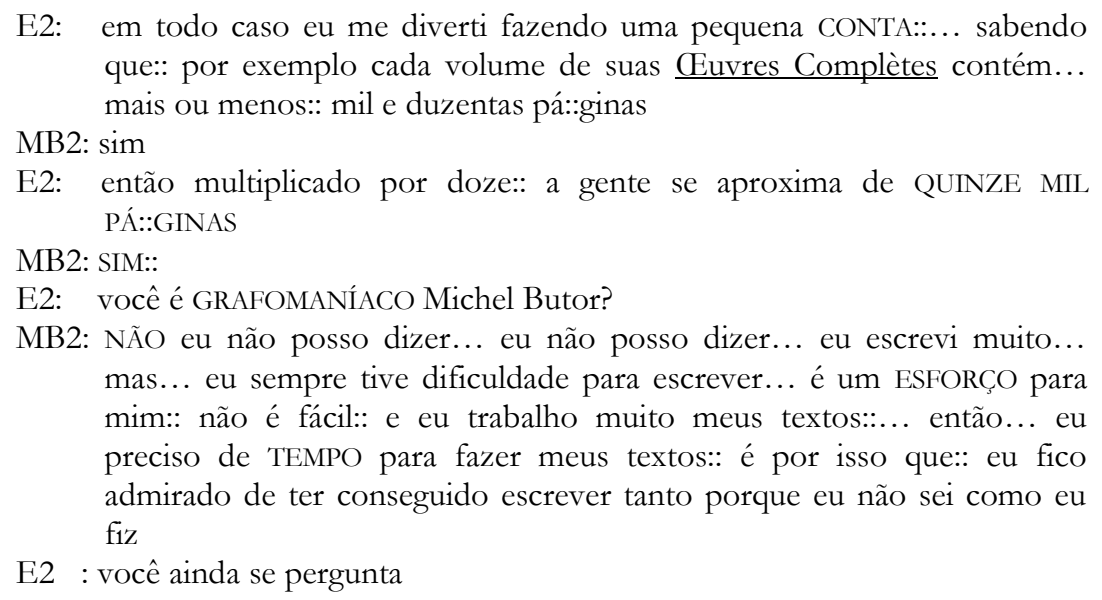

\footnotetext{
${ }^{6}$ Do original em francês: PUIS il y a LES LIVRES D'ARTISTES:: les livres d'artistes qui sont quelquefois imprimés:: qui sont quelquefois manuscrits... quelques fois REPRODUITS on fait par toutes sortes de procédés::.

${ }^{7}$ Do original em francês: travail:: ÉCLECTIQUE.

${ }^{8}$ Do original em francês: évidemment c'est difficile:: de:: GÉRER tout:: ça... .
} 
MB2: eu me pergunto... sim

Em resposta, Butor usará argumentos de dissociação para traçar uma imagem de si mais humanizada. Ao negar a suposição da entrevistadora, enfatizando o advérbio de negação, NÃO eu não posso dizer, bem como as lexias é um ESFORÇO para mim:: e eu preciso de TEMPO para fazer meus textos::; ele evidencia que seu trabalho depende de dedicação e de muito comprometimento para ser concebido, sendo, portanto, uma atividade intelectual, ligada a um esforço mental, não correspondendo a uma atividade mecânica da mão e esvaziada de sentido, como seria o caso de uma possível grafomania. Esse é um momento de correção da própria imagem que Michel Butor realiza sobre a apresentação de si feita pela entrevistadora à audiência de seu programa (Yanoshevsky, 2011), ao que ela tentará corrigir sua pergunta com uma nova reformulação, que será novamente corrigida pelo escritor com argumentos de dissociação:

E2: eu... o que eu tento:: compreender é:: você sempre foi bulímico de escritura:: por exemplo?

MB2: bulímico de LEITURA:: sim... eu sempre li muito... e... eu tinha uma PROFISSÃO:: que CONVINHA a isso:: porque eu era professor:: e depois de um certo tempo professor de literatura francesa e:: eu tinha necessidade então de LER muito e de RELER muito e isso:: isso foi MUITO ÚTIL para mim:: de ser obrigado a RELER continuamente os clássicos... percebe? pessoas como Hugo::... Balzac::... Molière:: eu reli não sei quantas vezes... Montaigne... se eu não tivesse sido professor:: eu certamente não teria relido... TANTO... e depois... eu sou curioso e então eu tenho vontade de descobrir outras literaturas... eu tenho SEMPRE coisas para ler::

Para essa nova correção, Butor enfatiza e prolonga as lexias que mais elucidam a dissociação por ele pretendida: bulímico de LEITURA:: sim...; eu tinha uma PROFISSÃO:: que CONVINHA a isso porque eu era professor::; eu tinha necessidade então de LER muito e de RELER muito e isso:: isso foi MUITO ÚTIL para mim:: de ser obrigado a RELER continuamente os clássicos...; pessoas como Hugo::... Balz̧ac::... Molière:: eu reli não sei quantas vezes... Montaigne...; se eu não tivesse sido professor:: en certamente não teria relido... TANTO...; eи tenho SEMPRE coisas para ler:: A função de professor aliou-se à própria prática de leitura do escritor - eu sempre li muito... -, possibilitando um contato contínuo com os clássicos, por meio da leitura e da releitura constante exigidas pelos cursos de literatura francesa que lecionou aos longo de décadas.

Nessa resposta, o escritor destaca os clássicos de Hugo, Balzac, Molière e Montaigne. Para Maingueneau (2001, p. 31), "qualquer escritor se situa numa tribo escolhida, a dos escritores passados ou contemporâneos, conhecidos pessoalmente ou não, que coloca em seu panteão pessoal e cujo modo de vida e obras lhe permitem legitimar sua própria enunciação". Os clássicos franceses legitimam, portanto, a obra de Michel Butor. Sendo ele leitor voraz e contínuo dos clássicos e tendo se empenhado em diversos estudos estilísticos sobre os cânones franceses, presentes nas séries Répertoire e Improvisations, Butor forma sua tribo composta de autores precedentes à sua geração, constituindo para si um panteão de peso e relevância literários. A leitura, ao contrário do que supõe a entrevistadora, ocupa lugar de destaque na vida do escritor, acima da própria escritura. O que Butor enfatiza é que ele escreve porque lê, e não o contrário. 
O ethos de aprendiz, de aluno e de herdeiro dos clássicos tem sua origem no seu trabalho de professor. É graças também a esse ofício que Butor afirma, no filme Michel Butor Mobile (Coulibeuf, 2001) ter sido capaz de se libertar das exigências editoriais e de poder ter liberdade para sua criação literária. Para ele, apresentar seu ethos de escritor exige, antes, a apresentação da sua narrativa de vida, evidenciando como a sua vida e o seu trabalho representam uma unidade (Machado, 2015, 2014), bem como o seu ofício de professor moldou toda a sua trajetória de escritor e de ensaísta. A narrativa de vida de Butor é, portanto, o cerne da constituição dos seus ethé, visto ser por meio do falar de sua vida imbricada em suas profissões - na de professor de sua língua materna e posteriormente na de professor de literatura francesa - que ele se apresenta.

E2: então... é... lendo... e escrevendo... sim

MB2: então... as duas coisas são MUITO LIGADAS pra mim porque a leitura ALIMENTA a escritura... sim... o que eu escrevo é no INTERIOR de um mundo de leitu::ra... eu sei bem que eu não sou O PRIMEIRO a escrever em francês ((riu)) então eu intervenho... no interior de uma literatura que já é ENORME... então minha escritura::... se produz no interior de um mundo de leitu::ra e... minha escritura... o fato que eu escrevo me faz LER DE OUTRA FORMA... porque:: eu busco sempre como se faz... percebe? ESSES TEXTOS que me encantam:: eu tenho vontade de OS IMITAR... e... então eu tento compreender como isso funciona

O jogo de pergunta e resposta desta parte da entrevista, composto pela sequência acima, explicita a relação estabelecida entre leitura e escritura para Butor. Praticamente, toda a enunciação do escritor é representativa de que sua obra possui forte herança nas leituras realizadas das obras de outros escritores: as duas coisas são MUITO LIGADAS pra mim porque a leitura ALIMENTA a escritura...; o que eu escrevo é no INTERIOR de um mundo de leitu::ra...; eu sei bem que eu não sou O PRIMEIRO a escrever em francês ((riu)) então eu intervenho... no interior de uma literatura que já é ENORME... . Sua escritura é composta de suas leituras dentro da imensidão da literatura francesa. O processo de escrita butoriano é alimentado pela leitura - ESSES TEXTOS que me encantam:: eu tenho vontade de OS IMITAR... . O escritor tem consciência da sua posição dentro da literatura francesa, que nasce na leitura, sendo esta a fonte de alimento para se criar sua própria obra, partindo da compreensão do fazer literário dos escritores canonizados e que são por ele admirados. Há, portanto, a apresentação de uma imagem de si de lucidez e de honestidade ao explicitar de forma muito clara ser a sua escritura calcada na leitura e no estudo que realiza de outros autores. Percebe-se também a descontração do escritor e o modo humorado como lida com a tessitura desses argumentos, marcados pelo riso, o que também é um indício de seu ethos e uma manifestação de seu corpo.

E2: Les poètes de sept ans:: então... poema de Arthur Rimbaud... com você... Michel Butor... Rimbaud certamente um MODELO:: para o poeta que você é?

MB2: SIM... ele me impressionou muito... quando eu era jovem... eu ficava completamente SURPRESO que:: alguém jovem como eu:: pudesse fazer coisas assim/ tenha feito coisas assim... e... então depois disso para mim foi um modelo inacessível porque... eu NÃO entendia como conseguir fazer como ele::... e depois pouco a pouco o estudando... tentando entender como foi feito:: então... então eu pude O IMITAR DE OUTRA FORMA... percebe? 
Após apresentar o poema de Arthur Rimbaud, E2 enfatiza a lexia MODELO para compor a pergunta ao escritor. Em resposta, Michel Butor enfatiza o advérbio de afirmação SIM... . Em seguida, será por meio de prolongamentos vocálicos e consonantais $^{9}$ que a argumentação será construída, dando ênfase nas lexias mais significativas: en ficava completamente SURPRESO que:: alguém jovem como eu:: pudesse fazer coisas assim/ tenha feito coisas assim...; para mim foi um modelo inacessivel porque... en NÃO entendia como conseguir fazer como ele::...; e depois pouco a pouco o estudando... tentando entender como foi feito:: então... então eu pude O IMITAR DE OUTRA FORMA... . Butor parte da surpresa pela poética de Rimbaud, passando pela incompreensão de como este outro jovem poeta fez o que fez, chegando no estudo desta poética que o surpreendeu para, por fim, ser capaz de O IMITAR DE OUTRA FORMA... . Evidencia-se, nesta enunciação, o rito genético de Michel Butor, visto que "a criação supõe, com efeito, a invenção de ritos genéticos específicos, de um modo de vida capaz de tornar possível uma obra singular" (Maingueneau, 2001, p. 48).

$\mathrm{Na}$ sequência da entrevista, E2 questiona a prática literária apresentada pelo escritor, estabelecendo o que pode ser considerada uma diretriz a ser seguida para se produzir uma literatura de qualidade. A ênfase dada nas mesmas lexias empregadas pelo escritor agem como forma de contestação e de julgamento de E2 do que foi dito por ele sobre seu método de escrita:

E2: mas COMPREENDER:: reproduzir::... IMITAR... isso não:: é suficiente para fazer a qualidade literária

MB2: NÃO... é preciso:: conseguir fazer ainda OUTRA COISA porque a qualidade:: literária é sempre a/ é sempre a novidade:: porque nós temos uma quantidade de coisas que já ESTÃO AQUI:: então não vale a pena/ NÃO VALE A PENA TENTAR FAZER A MESMA COISA... de qualquer maneira a gente não consegue... é sempre/ é sempre pior:: as imitações... então é preciso::... estudar... estudando:: tudo isso e bem tentar fazer melhor

Novamente, Michel Butor corrige a imagem de si projetada na entrevista pela jornalista (a partir de argumentos de dissociação) e a confusão que suas argumentações anteriores podem ter transmitido ao tratar da imitação. Percebe-se acima o efeito dos truncamentos em sua fala, que culminam com a ênfase em toda a locução após o penúltimo truncamento: porque a qualidade:: literária é sempre al é sempre a novidade::; então não vale a penal NÃO VALE A PENA TENTAR FAZER A MESMA COISA...; $e ́$ sempre/ é sempre pior:: as imitações... . Esse aparente eco gerado pelos truncamentos no discurso podem ser tanto resultado de uma ação da mente, que tenta recorrer ao que foi dito para corrigir a fala anterior sem entrar em contradição, como também de um cuidado e de uma atenção maiores para esclarecer pontos que ficaram soltos em seus argumentos anteriores. Por fim, ele esclarece seu processo de criação ao explicitar que este: (I.) nasce na leitura; (II.) seguida do estudo do funcionamento das obras que admira e; por fim, (III.) dando origem a uma criação hereditária desses outros autores; (IV.) mas que tenta dar um passo além, almejando assim a novidade e a qualidade literárias.

\footnotetext{
${ }^{9}$ Do original em francês: j'étais tout à fait:... SURPRIS que:: quelqu'un d'aussi jeune que moi:: puisse faire des choses comme ça...; pour moi c'était un modèle inaccessible:: parce que... je comprenais $P A S$ comment arriver à faire comme lui:....; et puis peu à peu en l'étudiant.:... en essayant de comprendre comment c'était fait:: alors... donc j'ai pu L'TMITER:: AUTREMENT... .
} 
A entrevistadora apresenta à audiência um fato do escritor não explicitado por ele até o momento, mas de grande importância para compreender as cinco décadas que separam a primeira dessa segunda entrevista:

E2: é preciso ainda relembrar::... que de uma certa forma a poesia tomou o lugar do romance no seu traba::lho depois de você ter publicado QUATRO ROMANCES

MB2: SIM

E2: ( ) e desde então:: STOP... não mais ficção... lugar a uma outra escritura:: e para explicar essa ruptura você disse DUAS COISAS:: APAIXONANTES "não fui eu quem deixou o romance... foi o romance que me deixou" primeiramente... e "o romance não é mais uma forma de atualidade diante dos novos modos de comunicação"... você poderia desenvolver isso... por favor... Michel Butor?

MB2: evidentemente é bem paradoxal porque se escreve uma grande quantidade de romances:: ( ) nunca publica::mos tanto... então o que eu quero dizer é que as pessoas OS LEEM:: de qualquer jeito... há inclusive muitas pessoas que leem romances:: e... é um pouco forte de dizer "o romance é um/ uma forma morta"

E2: e é isso que você disse... você

MB2: mas é isso que eu disse... é... porque é o sentimento que eu tenho::... o romance é uma forma absolutamente APAIXONANTE::... eu TRABALHEI:: MUITO:: com O ROMANCE... com OS GRANDES ROMANCES::... CLÁSSICOS NATURALMENTE... eu dei muitos CURSOS:: SOBRE Balzac:: Stendhal:: etcetera... eles fizeram um certo número de coisas COMPLETAMENTE MAGNÍFICAS... E HOJE... NÓS TEMOS OUTRAS NECESSIDADES... ENTÃO É POSSÍVEL SEMPRE TENTAR REFAZER DE TODA FORMA DE TODO JEITO O QUE ELES JÁ FIZERAM mais não é o mais interessante

Acima, o próprio escritor começa a explicitar o que ele entende por imitar e por buscar renovar na literatura através de fatos biográficos de sua vida, apresentados pela entrevistadora. Antes, porém, ele trata de uma afirmação feita pela jornalista, de uma certa forma a poesia tomou o lugar do romance no seu traba::Iho. Para elucidar a ruptura do escritor com o romance, E2 enuncia da seguinte forma as falas do escritor em outros momentos que não explicita, dando ênfase ao tempo de ruptura do escritor com o romance - que é o mesmo entre a primeira e esta segunda entrevista, ou seja, 50 anos desde a publicação do último romance pelo escritor - e ao modo como ela própria apreende essas falas: e para explicar essa ruptura você disse DUAS COISAS:: APAIXONANTES. O próprio escritor considera paradoxal essas duas afirmações precedentes que a jornalista apresenta para constituir seu ethos, sem portanto negar ou se desdizer, avaliando o tom que empregou nessas passagens como fortes, ao que ela reage ao constatar que, apesar de fortes, foi exatamente o que o escritor disse, e é isso que você disse... você, o que ele não nega, mas é isso que eu disse... é... porque é o sentimento que eu tenho::... . Para corrigir algum possível engano dessas falas precedentes, o escritor irá enfatizar as lexias que corroboram para o seu gosto pelo romance e para seus sentimentos: o romance é uma forma absolutamente APAIXONANTE::..; eU TRABALHEI:: MUITO:: cOM O ROMANCE... cOM OS GRANDES ROMANCES:.... CLASSSICOS NATURALMENTE...; eu dei muitos CURSOS:: SOBRE Balzac:: Stendhal:: etecetera...; eles fizeram um certo número de coisas COMPLETAMENTE MAGNÍFICAS..., o que corrobora com os diversos estudos que Butor realizou sobre os romances clássicos franceses presentes em suas obras completas. Após argumentar a favor do romance, Butor emprega a ênfase em argumentos que possam ilustrar a sua ruptura com essa forma literária e com o motivo de sua escolha: E HOJE... NÓS TEMOS OUTRAS NECESSIDADES... ENTÃO É 
POSSÍVEL SEMPRE TENTAR REFAZER DE TODA FORMA DE TODO JEITO O QUE ELES JÁ FIZERAM mais não é o mais interessante.

Outro ponto de grande importância para a compreensão do ethos nas entrevistas literárias deve-se às falas passadas do escritor trazidas para a cena enunciativa pela jornalista. Muito além de um mostrar-se através de sua maneira de se expressar (Amossy, 2005), o ethos autoral é construído também por enunciados com os quais ele não se identifica mais, mas que, ao entrarem na cena enunciativa, compõem a trama argumentativa que leva a audiência a ter uma imagem do escritor que, inclusive, foge ao controle autoral. A fluidez da entrevista literária, já apresentada anteriormente, é também resultado dos atravessamentos argumentativos e da própria narrativa de vida do escritor, que na entrevista literária não é o único apto a falar e a apresentar ao público a imagem do entrevistado. A entrevista literária é, portanto, conflituosa e ao mesmo tempo pacificadora, pois tende sempre a buscar estabelecer um equilíbrio entre os argumentos apresentados por ambos. Mas é tanto por meio desse equilíbrio quanto por intermédio dessas tensões apresentadas que o ethos autoral será forjado. Uma vez os argumentos apresentados, qualquer que seja o posicionamento do escritor, aqueles enunciados comporão sua imagem autoral.

Por fim, nessa segunda entrevista a relação de Michel Butor com as outras artes também será tratada, mas desta vez partirá da entrevistadora a construção da imagem de Butor em meio às parcerias de trabalho com outros artistas:

E2: Michel Butor como você compôs textos:: para esse novo álbum... eu tenho realmente a impressão que trabalhar com os outros... sejam eles músicos... pintores... ou artistas em geral:: isso lhe agrada muito mais que trabalhar... sozinho:: como se as outras expressões:: regenerassem seu estilo

MB2: mas certamente... os outros:: ME TRAZEM MUITO:: e... quando eu trabalho com os artistas:: SEJAM ELES PINTORES OU MÚSICOS... eu consigo dizer coisas que eu jamais diria sem eles... percebe? isso é... esse diálogo entre piano e:: texto::... é um texto que eu escrevi PARA ELE:: para Marc Copland... um pianista... realmente notável... então eu escrevi... para ele porque:: eu sentia que ele iria responder:: a isso... que isso lhe daria ideias a ele... e então eu fiz isso para ele... ( )

E2: SIM... eu vejo você sorrir::

[

MB2: SIM SIM

E2: cheio de alegria e de contentamento desse exercício

O sentimento de completude no fazer literário/artístico de Michel Butor vem da relação que ele estabelece entre literatura, pintura e música e das parcerias com artistas desses outros fazeres artísticos. Na primeira entrevista, ele enuncia que o seu contentamento com a obra de Proust vem da LIGAÇAO ABSOLUTAMENTE ESSENCLAL que essas duas atividades do espirito têm com essa terceira que é:: a literatu::ra. Vê-se acima as ênfases empregadas por Butor para destacar sua relação com as parcerias com outros artistas: os outros:: ME TRAZEM MUITO:: e... quando eu trabalbo com os artistas:: SEJAM ELES PINTORES OU MÚSICOS... eu consigo dizer coisas que eu jamais diria sem eles... .

Ao falar da parceria com Marc Copland, para a obra Le long de la plage, a ênfase PARA ELE:: destaca a própria produção butoriana pensada para compor uma parceria: esse diálogo entre piano e:: texto::... é um texto que eu escrevi PARA ELE:: para Marc Copland... um pianista... realmente notável... então eu escrevi... para ele porque:: eu sentia que ele 
iria responder:: a isso... que isso lhe daria ideias a ele... . Essa descrição de seu processo criativo pela parceria artística é de fundamental importância para a compreensão de sua obra, pois é uma obra que estabelece em sua gênese o diálogo entre texto e música, no caso dessa em específico, ou seja, trata-se de uma parceria que em sua origem estabelece a comunhão entre as artes, os diferentes domínios das expressões artísticas, transpassando a barreira que existe entre música, pintura e literatura. Michel Butor busca sempre o limiar entre as artes. Por conta disso, seu ethos autoral é composto também dessa comunhão, dessa troca com outros artistas.

A fala pausada do escritor, que trata do diálogo do piano e do texto, essenciais para se pensar esta pesquisa, é elucidada pela entrevistadora ao descrever a emoção que ele sente ao enunciar essas palavras, só perceptíveis aos espectadores quando ditas por E2: SIM... eu vejo você sorrir::, cheio de alegria e de contentamento desse exercício. Retomando Maingueneau, sobre como a noção de ethos recusa qualquer ruptura entre o texto e o corpo do enunciador (2001), deve-se à entrevistadora a presença do corpo do escritor na entrevista, que faz emergir para a audiência de seu programa o modo sorridente com o qual o escritor enuncia seu discurso.

Em resposta à constatação da jornalista, que pontua a felicidade de Butor ao falar da parceria com o músico Marc Copland, e ainda sobre a relação do escritor com as artes, para finalizar a entrevista, o escritor aproveita para trazer um fato biográfico de grande importância, também usando de pausa como recurso para destacar sua enunciação:

MB2: SIM SIM SIM... eu gosto muito... eu gosto muito de trabalhar com músicos... eu gosto muito de trabalhar com pintores e eu gosto muito de trabalhar com músicos... quando eu tinha VINTE ANOS... eu tinha vontade de ser músico e eu tinha vontade de ser pintor::... e:: entre os dois:: eu fiz literatura::... é isso... mas na minha literatura há sempre uma nostalgia da pintura e uma nostalgia da música... então quando eu trabalho com pintores... eu tenho a impressão de me tornar um pintor e quando eu trabalho com músicos... eu me torno um músico e eu sou feliz

A ênfase e os prolongamentos vocálicos e consonantais ${ }^{10}$ empregados pelo escritor, bem como as pausas, destacam a decisão que tomou em sua vida profissional ainda jovem. Michel Butor nutria o desejo de ser também pintor, sendo a sua outra opção a música. Ao invés de uma delas, ele escolheu a literatura: quando eu tinha VINTE ANOS... en tinha vontade de ser músico e eu tinha vontade de ser pintor::... e.: entre os dois:: eu fiz literatura::... é isso... . O escritor novamente reforça os argumentos anteriores de contentamento e de felicidade provenientes do trabalho de parceria - então quando eu trabalbo com pintores... eu tenho a impressão de me tornar um pintor e quando eu trabalbo com músicos... eи me torno um músico e eu sou feliz, -, sendo a sua própria literatura o lugar de encontro entre música e pintura: na minha literatura bá sempre uma nostalgia da pintura e uma nostalgia da música... . Esses enunciados finais do escritor corroboram com toda a trama argumentativa apresentada na entrevista, representando o ponto de conclusão e de harmonização das tensões geradas na co-construção de sua imagem autoral.

\footnotetext{
${ }^{10}$ Do original em francês: quand j'avais VINGT ANS... j'avais envie de faire de la musique et j'avais envie de faire
} de la peinture:.:. . et:: entre les deux::: j'ai fait de la littérature:.... voilà... . 


\section{CONSIDERAÇÕES FINAIS}

Michel Butor, romancista, ensaísta literário, crítico de arte e poeta, foi um dos grandes nomes da literatura francesa no século XX e no início do século XXI, vinculando-se aos grandes nomes da literatura clássica francesa, como Proust, Hugo, Balzac, Molière, Montaigne e Rimbaud. Sua produção monumental é repleta de livros de artista e de parcerias artísticas com pintores e músicos, o que faz de sua obra um grande desafio de pesquisa e a transforma em uma fonte quase inesgotável de possibilidades de análise, tanto linguístico-discursivas quanto literárias.

$\mathrm{Na}$ primeira entrevista, as imagens se co-constroem como uma reação do escritor à única pergunta enunciada pelo entrevistador, que vincula, por meio da técnica argumentativa de ligação, o ethos de Michel Butor aos ethé do próprio Proust e ao de seu leitor ideal, que só encontra no romance proustiano contentamento, êxtase e maravilhamento. A partir dos argumentos de dissociação, Butor apresenta seus ethé de: leitor e estudioso esforçado, apto a superar as próprias dificuldades em prol da literatura; aluno dedicado e humilde perante seu mestre (apesar de na época já ser um escritor aclamado tanto pelo público quanto pela crítica); escritor-construtor, que aprendeu com Proust a erigir um livro.

Já na segunda entrevista, a imagem do escritor é co-construída tanto por meio de elementos de dissociação argumentativa quanto por analogia e ligação argumentativas. O espaço de co-construção imagética é, portanto, de grande importância justamente pela constante presença da entrevistadora, que traz para a cena enunciativa diversas informações do escritor que não estariam presentes na entrevista se não fossem por ela. A entrevistadora, inicialmente, apresenta o ethos do escritor vinculado ao valor atribuído aos seus atos (Perelman; Olbrechts-Tyteca, 2005), buscando imediatamente corrigir a imagem por ela criada do escritor ao introduzir argumentos de dissociação do par aparência-realidade. Percebe que há por parte da E2 o objetivo de melhor apresentar o escritor à audiência do programa, fazendo com que o ethos de Michel Butor não seja só o da verossimilhança, mas o da verdade em si - evidenciando uma grande diferença entre a argumentação retórica (Breton; Gauthier, 2001) e a argumentação presente nas entrevistas literárias. Butor apresenta seu ethos em conformidade, em grande parte, ao que E2 constitui dele, por meio da confirmação dos elementos argumentativos de ligação apresentados por E2. É co-construído o ethos de escritor humilde diante de sua própria criação por ambos os sujeitos discursivos, sendo este ressaltando pelo ethos de trabalhador dedicado e de escritor profícuo. Destaca-se na segunda entrevista a constituição em cadeira cíclica dos ethé: o ethos de escritor liga-se ao ethos de professor, que se liga ao ethos de leitor, dando este origem ao ethos de estudioso e de pesquisador e, por fim, fechando o ciclo no ethos de escritor, que busca por meio do estudos dos cânones inovar na literatura francesa. Há ainda a presença do corpo na construção do ethos (Maingueneau, 2001) por meio dos risos, anotados no momento da transcrição, e dos sorrisos do escritor, indicados por E2, bem como do tom utilizado na enunciação (Machado, 2014), todos de grande importância para estabelecer a imagem do escritor.

A partir da análise de ambas as entrevistas literárias de Michel Butor, ficou evidente a imagem do escritor, seu ethos de escritor de fronteira - entre literatura, pintura e música -, de leitor e de estudioso dos clássicos por ele admirados da literatura francesa. O seu fazer literário é por ele traçado partindo da leitura, 
passando em seguida pelo estudo das obras lidas e, num terceiro momento, pela criação baseada nas técnicas dos escritores por ele admirados, em uma busca por tentar fazer algo inovador e que represente a sua identidade na literatura francesa. Essa identidade literária é composta também de parcerias com outros artistas músicos, pintores, ilustradores -, sendo por meio desses trabalhos que Butor encontra o que chama de felicidade e de completude em sua prática literária. É, portanto, essencial trazer à luz tanto as falas dos entrevistadores quanto as do entrevistado, visto que são as primeiras que orientam toda a argumentação, ou a contra-argumentação, do escritor. Por serem momentos ímpares de co-construção da imagem do autor, e graças às particularidades das entrevistas literárias e da constituição do ethos autoral nessa situação de comunicação, esse modelo de entrevistas possibilita análises ricas e de grande importância para os Estudos Literários e para a própria Análise do Discurso, por meio da Teoria da Argumentação como base de análise do ethos autoral.

Ressalta-se, ainda, que houve tanto mudança quanto manutenção do ethos de Michel Butor entre as duas entrevistas literárias. A mudança deve-se, sobretudo, à sua ruptura com o romance, como bem lembrado pela jornalista na segunda entrevista. Ele não enuncia, no decorrer dessa entrevista, os ensinamentos aprendidos tanto da obra de Proust quanto dos outros escritores que cita no que se refere ao romance; no entanto, ao contrastar a primeira e a segunda entrevistas, é possível observar que muito do que o escritor afirmou ter aprendido com Proust o acompanhou nesses cinquenta anos de produção literária. Os ethé de Michel Butor co-construídos mantêm a mesma essência na entrevista de 2013: de humildade, de reconhecimento do passado literário francês, de respeito aos cânones, de escrita baseada na leitura e no estudo dos clássicos franceses, de narrativa de vida imbricada na profissão (Machado, 2015). O trabalho de parceria com outros artistas é um elemento novo que surge na segunda entrevista, mas de total comunhão com a herança proustiana por ele destacada em 1963 e com os passos de seu fazer literário descritos em 2013. $\mathrm{Na}$ segunda entrevista, Michel Butor diz se sentir feliz e realizado quando trabalha em parcerias com músicos e pintores, retomando o vínculo entre literatura, pintura e música que ele aprendeu como lição em Proust, apropriando-se dessa herança e transformando-a ao longo dessas cinco décadas, sempre renovando e relacionando a literatura do século XXI às novas formas de se apresentar o texto, para além do romance.

\section{REFERÊNCIAS}

Amossy R. Argumentação e Análise do Discurso: perspectivas teóricas e recortes disciplinares. Piris EL, Ferreira MO, tradutores. EID\&A - Revista Eletrônica de Estudos Integrados em Discurso e Argumentação. 2011;1:129-144.

Amossy R. organizadora. Imagens de si no discurso: a construção do ethos. Cruz DF da, Komesu F, Possenti S, tradutores. São Paulo: Contexto; 2005.

Bakhtin M. A cultura popular na Idade Média e no Renascimento - o contexto de François Rabelais. Vieira YF, tradutora. São Paulo/Brasília: Hucitec/UnB; 2008.

Breton P, Gauthier G. História das Teorias da Argumentação. Carvalho M, tradutora. Lisboa: Editorial Bizâncio; 2001. 
Butor M, Fruchon-Toussaint C. À double titre: Michel Butor [programa de rádio]. Paris, Radio France Internationale, 03 ago. 2013. [citado 12 nov. 2018]. Disponível em

https:// savoirs.rfi.fr/br/apprendre-enseigner/culture/michel-butor.

Butor M, Gravier G, Vallette R. Proust aujourd'hui: La leçon de Marcel Proust selon Michel Butor [programa de rádio]. Paris, Radiodiffusion Télévision Française, 10 dez. 1963. [citado 12 nov. 2018]. Disponível em https:/ /www.youtube.com/watch?v=tlK0CeHO-ow\&t=232s.

Coulibeuf P. Michel Butor Mobile [filme cinematográfico]. Paris: Ministère des Affaires Étrangrères; 2001. 1 DVD; $61 \mathrm{~min}$.

Machado IL. O prefácio visto como uma prática discursiva em que diferentes vidas e obras se entrecruzam. Estudos Linguísticos. 2014;43(3):1129-1139.

Machado IL. Percursos de vida que se entremeiam a percursos teóricos. In: Santos S, Menezes W, organizadores. Discurso, Identidade, Memória. Fortaleza: Expressão Gráfica; 2015. p. 83-96.

Machado IL. Um encontro entre poesia, análise do discurso e narrativa de vida. PÓS - Revista do Programa de Pós-Graduação em Artes da Escola de Belas Artes da UFMG. 2016;6:32-43.

Machado IL. Uma analista do discurso face aos ditos de dois políticos: narrativas de vida que se entrecruzam. EID\&A - Revista Eletrônica de Estudos Integrados em Discurso e Argumentação. 2012;3:68-81.

Machado IL.A 'narrativa de si' e a ironia: um estudo de caso à Luz da Análise do Discurso. Cadernos Discursivos. 2013;1(1):1-16.

Maingueneau D. O contexto da obra literária. São Paulo: Martins Fontes; 2001.

Mello RA. Flaubert, Madame Bovary e Emma Bovary: ecos de ethos [dissertação]. Belo Horizonte: Faculdade de Letras, Universidade Federal de Minas Gerais; 2012.

Mello RA. O universo flaubertiano e a pathemização especular [tese]. Belo Horizonte: Faculdade de Letras da Universidade Federal de Minas Gerais; 2016.

Miranda DS. Discurso Jurídico: constituição do ethos e orientação argumentativa [dissertação]. São Paulo: Faculdade de Filosofia, Letras e Ciências Humanas, Universidade de São Paulo; 2011.

Oliveira RR. Uma outra face feminina: retórica, argumentação e ethos em entrevistas de Hilda Hilst. EID\&A - Revista Eletrônica de Estudos Integrados em Discurso e Argumentação. 2016;11:103-116.

Perelman C, Olbrechts-Tyteca L. Tratado da argumentação - a Nova Retórica. 2a edição em português. Galvão ME de AP, tradutora. São Paulo: Martins Fontes; 2005.

Perugini GPD. Déconstruction et reconstruction chez Michel Butor et Alain Robbe-Grillet: contribution du nouveau roman à l'imaginaire social des Trente glorieuses (1946-1975) [tese]. Lille/São Paulo: École Doctorale Sciences de l'Homme et de la Société/Faculdade de Filosofia, Letras e Ciências Humanas, Université Charles de Gaulle - Lille III/Universidade de São Paulo; 2015.

Prado DS. A recepção do 'novo romance' no 'Suplemento literário' do jornal O Estado de São Paulo [dissertação]. São Paulo: Faculdade de Filosofia, Letras e Ciências Humanas, Universidade de São Paulo; 2006.

Yanoshevsky G. A co-construção da imagem do autor: o caso da entrevista literária. In: Emediato V, Lara GMP. Análises do Discurso Hoje. Rio de Janeiro: Nova Fronteira; 2011. Vol. 4. Não paginado.

Yanoshevsky G. L'entretien littéraire - un objet privilégié pour l'analyse du discours? Argumentation et Analyse du Discours [En ligne]. 2014:12: não paginado. [citado 20 nov. 2018]. Disponível em http:/ /aad.revues.org/1726. 